\title{
Analysis on the Sustainable Development of Gong Cha
}

\author{
Anqi Zhang ${ }^{1}$ \\ ${ }^{1}$ Monash University, Mel, VIC, Australia \\ Correspondence: Anqi Zhang, Monash University, Mel, VIC, Australia. Tel: 61-41-599-1670.
}

Received: October 29, 2019

Accepted: November 14, 2019

Online Published: December 14, 2019

doi:10.20849/abr.v4i3.684

URL: https://doi.org/10.20849/abr.v4i3.684

\begin{abstract}
We selected Gong Cha Monash branch as the research object, conducted a research focusing on four topics which is Food supply chain, Packaging, Procurement and Transport/distribution, and obtained data through on-site interview, email consultation and questionnaire survey.

There are some findings after analysing the collected data. Firstly, the main finding of food supply chain is that Gong Cha used Franchising system; all of the quality of materials can be controlled by head office. Although tribute tea has very little food waste, they waste a lot of water resources. Secondly, the main finding of packaging is that Gong Cha uses about 800 disposable plastic cups and straws in PE and LL materials a day, and about $20 \%$ customers choose to use another plastic carry bag to carry the drinking. All these raw materials in Gong Cha are transports in cartons, foam paper, and plastic bags and only the cartons are recycled. Thirdly, the main finding of procurement is that there is a storehouse nearby Monash's sub-branch to provide relevant materials once per week or the employees can go to the storehouse to acquire materials everyday if they need. In order to keep the same standard of product taste or quality, all the raw materials are originated from Taiwan. The in-store containers are reused products, such as aluminum containers for tea and tea-leaves and recycled plastic boxes for pearl and puddings. Finally, the main finding of distribution is that, tea materials are shipped from Taiwan twice a week. Trucks are used for transportation between stores and warehouses. Gong Cha's use of American-invested power distribution equipment, which uses more light, water or energy than any other, violates Monash's network of sustainable solutions. Gong Cha does not offer any training on how to use the equipment sustainably.
\end{abstract}

Keywords: sustainable supply chain, food supply chain, strategy, sustainability

\section{Introduction}

Milk tea has become a new trend in Melbourne. At Monash University Caulfield, a new milk tea shop, Gong Cha, is one of Asia's most popular brands. We selected Gong Cha Monash branch as the research object, conducted a research focusing on four topics which is Food supply chain, Packaging, Procurement and Transport/distribution, and obtained data through on-site interview, email consultation and questionnaire survey (in the appendix). This paper will first briefly introduce the business background of gong cha, then analyse the collected data in combination with the sustainable development policy and relevant theories of Monash university, and finally make Suggestions for our main findings.

\section{Background}

Gong Cha international co., ltd. is a large-scale chain of beverage stores established in Kaohsiung, Taiwan. It was established through franchising in 2006 and established its first overseas branch in Hong Kong in 2009. Since then, its business has expanded rapidly to other parts of Asia, including Australia and North America, with more than 1,500 stores worldwide. Gong Cha offers 13 series of drinks, including milk tea, coffee, smoothies and so on. All the tea is brewed in the shop every day. Natural, healthy and fresh drinks are the core competitiveness of Gong Cha. Selection of raw materials and good service are the characteristics of Gong Cha. (Gong Cha, n.d., 2019)

\section{Discussions}

\subsection{Major Finding}

3.1.1 Findings of Procurement

Firstly, the frequency of purchase of raw materials: There is a storehouse nearby Monash's subbranch to provide 
relevant materials once per week or the employees can go to the storehouse to acquire materials everyday if they need. And secondly, Gong Cha's Purchasing strategy: In order to keep the same standard of product taste or quality, all the raw materials are originated from Taiwan. Finally, the in-store containers are reused products, such as aluminum containers for tea and tea-leaves and recycled plastic boxes for pearl and puddings.

\subsubsection{Findings of Packaging}

Through physical inspection and interview, we find that Gong Cha uses a lot of packaging. Since Gong Cha is only for takeout, it uses about 800 disposable plastic cups and straws in PE and LL materials a day, and about $20 \%$ customers choose to use another plastic carry bag to carry the drinking. Meanwhile, ingredients such as tea bags, pearls, and puddings are stored in plastic bottles for continuous using. In addition, all these raw materials in Gong Cha are transports in cartons, foam paper, and plastic bags and only the cartons are recycled.

\subsection{Minor Finding}

\subsubsection{Findings of Food Supply Chain}

Gong Cha is a Taiwanese global chain drink store, their main raw materials include different types of Chinese tea, such as green tea, oolong tea, black tea and flower tea, and pearl. Based on the outcomes of the interview, all tea is planted in Taiwan and transport to Australia and other food materials almost come from mainland China. All of the raw materials passed the authoritative quality inspection system from Taiwan or mainland China. (Gong Cha, n.d., 2019) The staffs are not very concerned about the origin of the food raw materials, because of Gong Cha used Franchising system, all of the quality of materials can be controlled by head office. And then they transport all of the materials to the main warehouse and regional warehouse. Although Gong Cha has a complete supply chain system for all franchisee to control the quality and make sure they can operate normally, they still have many sustainable development problems. Although tribute tea has very little food waste, they waste a lot of water resources. The staff said Gong Cha usually set the store in crowded areas, and they cannot to clean up the tools on time; therefore, they always place all tools in the sink and continue to rinse with running water. And the staff the only way can solve water waste is to increase the number of employees and expand the store size. The Gong Cha store in Monash has no description of recyclables.

\subsubsection{Findings of Transport and Distribution}

We have interviewed the manager about the transport and distribution policy. We could analysis whether these policies consistent with the Monash sustainable supply chain policy. We will provide more recommendations.

Firstly, we found that Gong Cha collected the finest green teas such as green tea and high-altitude tea from Alishan which locate in Taiwan. (Gong Cha website, 2019) So, it would lead to a question about the transaction. When we interviewed the manager about the purchase frequency of raw materials. They told us they committed to select the freshest materials, which means that every day, the employee delivery the tea materials from the warehouse near the campus and twice a week, the tea material would be delivery from Taiwan. We also found that they preferred to use truck between the store and warehouse. But they did not have any measurement on the vehicle routine so that control the cost or any waste in the transaction process.

At the same time, the manager introduced the most advanced international drinking water treatment equipment so that the two basic elements of tea, water and ice, could be as pure and tasteful as natural mineral water. We found that the distribution equipment invested from the united states also needs a relative higher usage of light, water or energy than others, which also breach the sustainable solutions network of Monash university. We also found that the equipment would use twice electricity than others if the employee could not understand how to use the special saving standard. In addition, they did not provide any trainings course about how to sustainability use the equipment. The manager told us that they established numbers of warehouses near the store which could save the cost of delivery.

\section{Analysis}

\subsection{Analysis of Food Supply Chain}

Because of the bubble tea originated in Taiwan and Gong Cha is a famous Taiwan bubble tea brand, its suppliers almost from Taiwan and mainland China. Their most important suppliers are tea merchant, because Chinese is hard to grow in Australia and other Western countries. Supplier selection is the first part of Gong Cha's supply chain management, it will influence transportation, packaging, and food processing. All tea materials can be grown in Mainland China or Taiwan, so careful selection of suppliers and similar place of delivery can reduce transportation costs effectively from suppliers to main warehouse in Melbourne and also reduce transportation consumption and emissions. And if suppliers almost from similar area, the company can easy to control the 
quality of materials and reduce the order cycle. Monash want to increase their usage of organic products (Monash University, 2016), but all of Gong Cha's food materials are hard to monitor by Monash, because those materials come from Taiwan and Mainland China.

The last part of Gong Cha's supply chain is food waste and recycling. Gong Cha has less food waste during the whole process, almost food waste is used tea leaves. Gong Cha did not has own recycling system and they also did not promote recycling to Monash university students. According to the interview of staffs, they are doing not care about the recycling policy of Monash University and only know the policy of classified garbage.

\subsection{Analysis of Packaging}

As we find that Gong Cha uses lots of packaging mostly in three stages.

\subsubsection{Transit Packaging}

Transit is the first stage for Gong Cha to use packaging. All raw materials like tea bags, cups and milk are carried in packaging. Generally, plastic bags are used as the first layer and then using foam paper to reduce the buffering of goods, and finally, cartons are used to wrap the goods. In this stage, only the cartons are recycled and other foam papers and plastic bags are thrown away.

The action to recycle the cartons accords with the sustainability policies set by the Monash that recovering resources for re-use and recycling.

However, throwing plastic bags and foam papers are unsustainable. On one hand, as manufacturing the plastic bag and foam paper consume oil and gas, they are non-renewable resources. On the other hand, as Billings (2010) said that one of the most public battlegrounds over claims of unsustainable processes centers on waste and, specifically, on product packaging.

\subsubsection{Storage Packaging}

Storage is the second stage for Gong Cha to use packaging. After goods are transported to the store, Gong Cha uses lots of big plastic bottles instead of plastic bags to fill them and use them after. These big plastic bottles will not be thrown away when they are used up but will be refilled. Gong Cha's action of re-use can recover the resources and reduce waste. These reuse bottles have a better environmental impact than single-use bottles.

\subsubsection{Retail Packaging}

Retail is the last stage for Gong Cha to use packaging. All the orders in Gong Cha use the packaging because of Gong Cha only for takeout. Gong Cha provides disposable cups and straws for customers, it is an effective way for Gong Cha to fit customers' needs and fit own purpose to sell drinking. However, it is unsustainable. Darby Hoover, Natural Resources Defense Council, said 'single-use food and beverage packaging is a prime component of the plastic pollution in our oceans and waterways, which kills and injures marine life and poses a potential threat to human health'. Moreover, orders, including cups, plates, and straws partially degrade and harm marine life (Wilson, 2008). Through Monash Environmental Sustainability, most disposable cups are not recyclable due to the plastic membrane that lines them. They contaminate our recycling and can take up to 50 years to degrade in a landfill. Glasses cups and own cup are not available for the time being in Gong Cha, which contradicts to Monash Sustainability Team's "Borrow Cup" and "Reusable Cup" activities. These activities are aimed to reduce waste to landfill and make the campus more sustainable.

\subsection{Analysis of Procurement}

For the frequency of purchase of raw materials, the Green Purchasing strategy of Monash is to choose a product with the least environment influence.

Gong Cha implements this Monash's strategy well in the aspect of in-store containers and frequency of purchase of raw materials for the considers economic, social and environmental impacts of sustainable procurement. (Meehan \& Bryde, 2011) In the aspect of economy, building a storehouse nearby the subbranch of Monash improves the cost for the short-term of Gong Cha. For the long-term, the cost per item is lower, compared with the subbranch which does not have a storehouse nearby it. The Monash subbranch of Gong Cha can be supplied by the recent storehouse with a short time drive. In order to ensure the quality of raw materials, the delivery of raw materials needs to be on time (once per week). Higher frequency of supplying ensures the higher quality of products. However, if Gong Cha does not provide the nearby storehouse to provide materials, the long travelling of supply chain costs more and if Gong Cha reduces the supplying frequency, the quality of product cannot be guaranteed. In addition, for the social aspect, a nearby storehouse improves the procurement effectiveness, reducing the conflicts between employees and simplifying the supply chain management. Because the employees can independently go to the storehouse to acquire their needs, it avoids the conflicts of not in time delivery. 
Moreover, for the environmental aspect, setting a storehouse nearby subbranch of Gong Cha reduces the consumption of energy during the transportation. Amount of cargos can be transformed once from the central storehouse to the sub-storehouse, saving consumption of energy during the transportation. Therefore, Gong Cha's purchase frequency strategy copes with Monash's Green Purchasing strategy.

For the purchasing strategy, The Green Purchasing strategy of Monash is to choose a product which contains recycled materials and consider the end-of-life options for a product.

Gong Cha responses well to the first strategy but not the second. The tea beverage is Gong Cha's main products, it is difficult for Gong Cha to provide reused cup for the consumers because building up a bottle recycle system needs a retailer's system of collection and delivery which based on a large scale of business system (Vaughan et al., 2007). In order to standardize and ensure the product quality, all the materials, tea, pearl and packages are originated from Taiwan. The packages are paper boxes or plastic cups which can be recycled, coping with the Monash's Green Purchasing strategy of the requirement of recycled materials. However, considering to the life cycle analysis theory, calculating the influences on the environment of the product from its raw materials from the earth to the end of all materials back to the earth (Ayres, 1995), this procurement strategy has not fully responded the needs of Monash's Green Purchasing strategy. First, the plastic bags are manufactured by polypropylene (Gong Cha, 2019) which cannot be biodegraded in the natural environment. Second, the transportation of packaging materials from Taiwan increased wastes of energy, compared with local procurement. Therefore, Gong Cha's purchasing strategy does not well respond to the requirement of Monash's Green Purchasing strategy.

\subsection{Analysis of Transport and Distribution}

Transport as a whole account for $19 \%$ of global energy use and $23 \%$ of energy-related carbon dioxide $\left(\mathrm{CO}_{2}\right)$ emission. (International energy agency, 2009) The long-distance delivery and frequency delivery using truck would produce more carbon dioxide emission. We found that the most of transportation is environmental-friendly and saving-energy in Monash sustainable policy. When corporation analysis their sustainable management, they need to consider the energy spend on transaction. (Transactions on sustainable energy, 2013). Obviously, Gong cha only consider how to satisfy the economic aspect to attractive more loyalty customers not the environmental conditions.

However, when we discussed with the manager about the distribution location, they told us that they established numbers of warehouses near the store which could save the cost of delivery. But they still admitted the multiple facilities spend more on the usage of light, water or energy. When we look through the Monash university sustainable development solutions network, they ensure access to reliable and sustainable energy. If we consider the assessment of the environment in the food supply chain, we will reduce the influence on the distribution cost (Jones, 2002). Gong cha could not assessment whether their policy is sustainable or not. Another finding relates to the distribution part was that manager refused to tell us about the specific electricity consumption and their corporation strategy about how to control waste of the electricity or provide any trainings to educate their employee.

\section{Recommendation}

\subsection{Recommendation for Food Supply Chain}

The first recommendation of the food supply chain is about select suppliers. Gong Cha's suppliers almost from Taiwan and Mainland China, so they are purchased and ship from both areas. According to the staff said the raw materials from Taiwan are 3 times expensive than Mainland China and Mainland China has the most Gong Cha stores. Because purchasing food from the different area will increase the cost of material and shipping, we recommend that Gong cha can buying some food materials from Mainland China, those food which is not unique in Taiwan, such as flower tea; because Chinese tea has high quality and some tea are better than Taiwan. Gong Cha also can remain their purchase strategies, but they should bring all ingredients together in a nearby warehouse and then transport them to Australia, the large-scale transportation can reduce transportation costs while reducing emissions during transportation and other environmental impacts. Mainland China is one of the best teas producing regions in the world and most of the tea used in Gong Cha originates in mainland China. One of Gong Cha's staff which come from Taiwan, she said the raw materials from Taiwan are 3 times expensive than Mainland China and Mainland China has the most Gong Cha stores. Thus, Mainland China can be the sole supplier for Gong Cha.

The second recommendation for supply chain is about recycling measures, because all most food waste is used tea leaves, Gong Cha can develop its value for promote recycling and secondary production. The used tea leaves 
can be used from several ways such as, it can be made as plant fertilizer and also can be made into a deodorant (Bird and blend tea, 2019), those secondary commodities are both in line with sustainable development strategies and increase company profitability.

\subsection{Recommendation for Packaging}

Overall, the packaging use of Gong Cha is not sustainable and not in conformity with Monash University sustainability policies. To become more sustainable and consistent with Monash University sustainability policies, Gong Cha can encourage customers to bring reusable cups to drink.

Using disposable cups and straws are not environmentally friendly and sustainable. Therefore, encouraging customers to bring reusable cups to drink in the retail stage is a good way for Gong Cha to reduce packaging and be more sustainable because retail is the most-used stage for packaging. When customers use their cups to fill the drinks, fewer straws will be used also, because own cups are seldom sealed. Using own cup to drink is also in line with Monash University Sustainability policies to remove single-used cups and disposable cups for the university.

Gong Cha can learn Starbucks's campaign. Starbucks has launched "Take the Mug Pledge" campaign for many years (Pangburn \& Avdinliyim, 2012). Because bring own cup leads an inconvenience to customers, Starbucks has offered a discount (about 10\%) for the customer who purchases coffee without a standard disposable cup to encourage and reward customers' environmental behaviour.

Starbucks is a good example of Gong Cha to learn. However, there are still some challenges for Gong Cha to overcome. Gong Cha is not sold in cups now, so when customers bring their own cups of different sizes, it is confused for Gong Cha to determine the size of a cup. However, Starbucks does not have to worry about this problem because they sell cups and it is a good way to promote their cups. At the same time, the size of the discount needs to be further studied. The discount should ensure that it is attractive to customers without the reduce of Gong Cha's profits.

Aside from bringing own cups, Gong Cha can also collaborate with Monash University on "Borrow Cups" and "Reusable Cup "activities. Gong Cha can be a retail location to sell Monash KeepCup. In this way, students buy the reusable cup and get the drinks at a discount. And Gong Cha gets deal base from university in collaboration. Additionally, Gong Cha can set up a Borrow Cup spot to provide Borrow Cup for the student to fill the drinks and popularize this sustainable activity. This way requires Gong Cha to communicate with the activity leader and carry out the cooperation not only protect each interest but also make the university more sustainable.

\subsection{Recommendation for Procurement}

For the procurement strategy, Gong Cha implements well in the aspect of the frequency of purchase of raw materials but not reasonable in the aspect of the purchasing strategy of packaging.

In order to improve its sustainability strategy, first, Gong Cha could consider with the local procurement of paper and plastic packages. Local factories may have different producing standard for the beverage packages, but it will not influence the taste of beverage of Gong Cha. At the same time, local purchasing strategy reduces the energy of transportation because there is no need of air or sea transportation.

Second, even though the polypropylene is a recyclable material, it cannot be naturally biodegraded. If the plastic packages are discarded randomly, the negative influence is serious. In order to implement sustainability strategy better, Gong Cha should consider biodegraded packages instead of the current ones.

Local procedure may increase the cost of beverage package, compared to the lower labor cost in Taiwan. Considering to the higher retail price in Australia, the higher costs in package is acceptable. In addition, the benefit to the environment will save a significant number of costs in the future.

\subsection{Recommendation for Transport and Distribution}

Based on these major finding, Gong cha will confront many challenges in the sustainable food supply chain process.

Firstly, the higher pressure on the climate change because of the frequency of trunk or Large fuel consumption vehicle. We suggest that they could investment more advanced vehicle with lower fuel consumption. Then, Gong cha also could establish more flexible contract which could support them to calculate the reality usage of the time and fuel in the delivery process. They need add these data into their strategy to assessment the environment performance.

Secondly, they could select more cleaner equipment to transfer the distribution equipment. They also could hire 
more professional expert to track the performance of the equipment, such as fuel, energy and electricity. The cost of investment could develop their ability to centralize the capital expense. In addition, they could provide training course about how to effectively use the equipment to enhance the sustainability awareness of the employee.

Thirdly, the IT department could analyse the delivery route between the store and warehouse. They could focus on the minimum time, distance and cost to support the delivery department. This route results could help them to choose the most suitable distance to establish the distribution centre. This is because the main or multiple facilities all have different emission.

Lastly, Gong cha could select some similar raw material in Australia. In the one hand, the resource could be more near the distribution location to reduce the transaction pollution, on the other hand, the long-distance delivery also influences the cost of the corporation.

\section{References}

Ayres, R. U. (1995). Life Cycle Analysis: A Critique. Elsevier Science, 199-223. Retrieved from https://www.sciencedirect.com/science/article/pii/092134499500017D

Billings, S. (2010). Planet packaging. Marketing, 31-33. Retrieved from https://search-proquest-com.ezproxy.lib.monash.edu.au/docview/214959355?accountid=12528

Bird and blend tea. (2019). 7 top tips for recycling your used tea leaves. Retrieved from https://birdandblendtea.com/uk_en/universitea/recycle-used-tea-leaves

Gongcha. (2019). PP Cup. Retrieved from http://www.gong-cha.com/tw/safe. php?act=view\&no=38

Gongcha. (2019). Raw materials. Retrieved from http://www.gong-cha.com/tw/safe.php?cid=1

Jones, A. (2002). An environmental assessment of food supply chains: A case study on dessert apples. Environmental Management, 30(4), 560-76. https://doi.org/10.1007/s00267-002-2383-6

Meehan, J., \& Bryde, D. (2011). Sustainable procurement practice. Business Strategy and the Environment. https://doi.org/10.1002/bse.678

Monash University. (2016). Monash signs landmark agreement on Sustainable Development Goals. Retrieved from https://www.monash.edu/news/articles/monash-signs-landmark-agreement-on-sustainable-development-goa 1s

Monash University. (2019). Environmental Sustainability. Retrieved from https://www.monash.edu/environmental-sustainability/campus-initiative/reusable

Pangburn, M. S., \& Aydinliyim, T. (2012). Reducing packaging waste and cost via consumer price discounts. Decision Sciences, 43(6), 1063-1089. https://doi.org/10.1111/j.1540-5915.2012.00385.x

Transactions on Sustainable Energy. (2013). IEEE Transactions on Power Systems, 28(2), 2048. https://doi.org/10.1109/TPWRS.2013.2258533

Vaughan, P., Cook, M., \& Trawick, P. (2007). A Sociology of Reuse: Deconstructing the Milk Bottle. Wiley Online Library. https://doi.org/10.1111/j.1467-9523.2007.00432.x

Wilson, R. (2008). DESIGN AND PACKAGING: Reduce, reuse, recycle. Marketing Week, 27. Retrieved from https://search-proquest-com.ezproxy.lib.monash.edu.au/docview/228248064?accountid=12528 


\section{Appendix}

Analysis Part 1

\section{Compulsory Questions}

Findings

\section{Support from the Major/Minor findings interview responses}

To what extent the businesses are aware of the Monash University sustainability policies (based on the four topics)

Tips:

Are they aware of the policies? If so, how much knowledge they have? Knowledge is only there at the management level or at the worker level too?

Almost staffs in The staffs said they are did Gong Cha not pay attention to Caulfield campus sustainability and they also did not know any did not have any training information about about sustainability Monash University sustainability policies. policies in Monash University.

If no knowledge, why not?

To what extent the businesses follow the sustainability policies set by the Monash University

The business $\begin{aligned} & \text { Almost sustainability } \\ & \text { followed } \\ & \text { overall. in }\end{aligned}$
strategies within the Gong
Cha is controlled by the
main company.

Tips:

Do they follow in detail or overall? In either case, why?

What have been achieved and/or what have not been achieved so far

There are all tea are Natural organic.

Tips:

Provide a list of things they considered 'achievements'. Do you think these are real 'achievements'?

The use recyclable cartons to wrap all materials.

List the things they did not achieve.

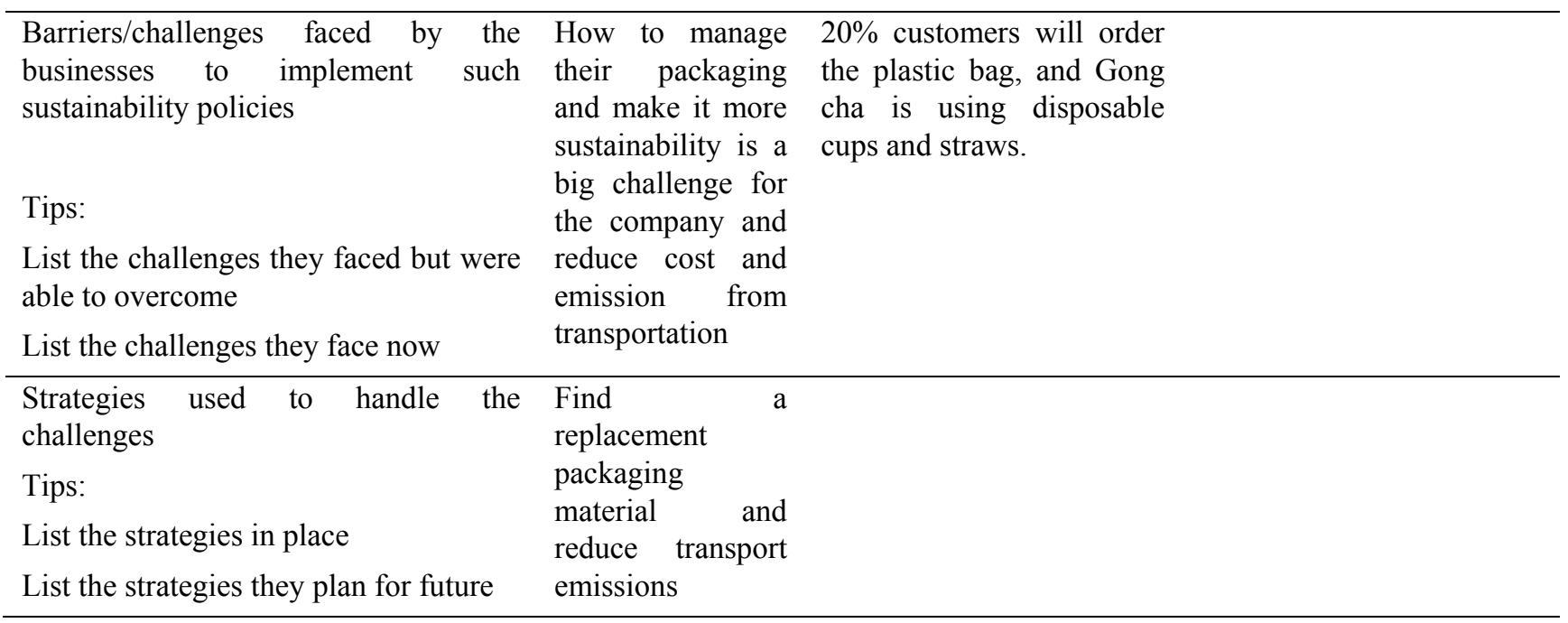


Analysis Part 2

\begin{tabular}{|c|c|c|c|}
\hline $\begin{array}{l}\text { Topic-related questions (any Findings } \\
4 \text { topics) }\end{array}$ & $\begin{array}{l}\text { Support from the } \\
\text { interview responses }\end{array}$ & $\begin{array}{l}\text { Major/Minor } \\
\text { findings }\end{array}$ & The theory \\
\hline \multirow{2}{*}{\multicolumn{4}{|c|}{$\begin{array}{l}\text { Tips: } \\
\text { Have } 4 \text { separate tables with } \\
\text { questions and responses as } \\
\text { above }\end{array}$}} \\
\hline & & & \\
\hline 1.Food supply chain & $\begin{array}{l}\text { All most food materials } \\
\text { from Taiwan and } \\
\text { Mainland China }\end{array}$ & $\begin{array}{l}\text { Low waste of food } \\
\text { and material origin } \\
\text { is Taiwan and } \\
\text { Mainland China }\end{array}$ & \\
\hline \multirow[t]{2}{*}{ 2. Procurement } & \multirow{2}{*}{$\begin{array}{l}\text { Procurement strategy is } \\
\text { purchase fresh food and } \\
\text { valuable raw materials } \\
\text { from Taiwan and } \\
\text { Mainland China }\end{array}$} & \multirow{2}{*}{$\begin{array}{l}\text { The high frequency } \\
\text { of purchase of raw } \\
\text { materials. }\end{array}$} & $\begin{array}{l}\text { The life cycle } \\
\text { analysis theory }\end{array}$ \\
\hline & & & $\begin{array}{l}\text { Triple bottom line } \\
\text { theory }\end{array}$ \\
\hline 3. Packaging & $\begin{array}{l}\text { Multiple packaging in } \\
\text { shipping and many } \\
\text { packaging for customers. }\end{array}$ & $\begin{array}{l}\text { Gong Cha uses a } \\
\text { lot of packaging. }\end{array}$ & $\begin{array}{l}\text { Types of } \\
\text { packaging }\end{array}$ \\
\hline 4. Transport and distribution & $\begin{array}{l}\text { The shop has daily and } \\
\text { weekly order from } \\
\text { warehouse by trucks or } \\
\text { staffs. }\end{array}$ & $\begin{array}{l}\text { The transportation } \\
\text { distance is long, the } \\
\text { large quantity of } \\
\text { materials and high } \\
\text { frequently leads to } \\
\text { an increase in } \\
\text { displacement. }\end{array}$ & \\
\hline
\end{tabular}

Analysis Part 3a (Recommendations for major findings)

Tip: you need separate major findings for each four topics.

\begin{tabular}{|c|c|c|c|c|}
\hline $\begin{array}{l}\text { Topic-related findings (any } \\
4 \text { topics) }\end{array}$ & $\begin{array}{l}\text { Major } \\
\text { Findings (1 } \\
\text { or 2) }\end{array}$ & Recommendations & $\begin{array}{l}\text { Timeline } \\
\text { (short term or } \\
\text { long term) }\end{array}$ & The theory \\
\hline \multicolumn{5}{|l|}{ Food supply chain } \\
\hline Packaging & $\begin{array}{l}\text { Gong Cha } \\
\text { uses a lot of } \\
\text { packaging. }\end{array}$ & $\begin{array}{l}\text { Encouraging customers to } \\
\text { bring reusable cups } \\
\text { Gong Cha can also } \\
\text { corporate with Monash } \\
\text { Sustainability Team in" } \\
\text { Borrow Cup"and } \\
\text { "Reusable Cup" activities. }\end{array}$ & Short term & $\begin{array}{l}\text { Purpose behind } \\
\text { packaging }\end{array}$ \\
\hline Procurement & $\begin{array}{l}\text { The high } \\
\text { frequency of } \\
\text { purchase of } \\
\text { raw } \\
\text { materials. }\end{array}$ & $\begin{array}{l}\text { Gong Cha could consider } \\
\text { with the local procurement } \\
\text { of paper and plastic } \\
\text { packages. } \\
\text { Gong Cha should consider } \\
\text { biodegraded packages } \\
\text { instead of the current ones. }\end{array}$ & Long term & $\begin{array}{l}\text { The life cycle } \\
\text { analysis theory } \\
\text { Triple bottom } \\
\text { line theory }\end{array}$ \\
\hline
\end{tabular}


Analysis Part 3B (Recommendations for minor findings)

Tip: you can have separate minor findings for each four topics or can have them together at the end.

\begin{tabular}{|c|c|c|c|c|}
\hline $\begin{array}{l}\text { Topic-related findings (any } \\
4 \text { topics) }\end{array}$ & $\begin{array}{l}\text { Minor } \\
\text { Findings (1 or } \\
\text { 2) }\end{array}$ & Recommendations & $\begin{array}{l}\text { Timeline } \\
\text { (short term or } \\
\text { long term) }\end{array}$ & The theory \\
\hline Food supply chain & $\begin{array}{l}\text { Low waste of } \\
\text { food and } \\
\text { material origin } \\
\text { is Taiwan and } \\
\text { Mainland China }\end{array}$ & $\begin{array}{l}\text { The starting point for } \\
\text { unifying raw material } \\
\text { transportation; } \\
\text { Secondary processing of } \\
\text { used tea leaves and sales of } \\
\text { secondary processed } \\
\text { products. }\end{array}$ & Long term & $\begin{array}{l}\text { Total cost } \\
\text { approach; } \\
\text { Mode of } \\
\text { transportation. }\end{array}$ \\
\hline Packaging & & & & \\
\hline Procurement & & & & \\
\hline Transport/distribution & $\begin{array}{l}\text { The } \\
\text { transportation } \\
\text { distance is long, } \\
\text { the large } \\
\text { quantity of } \\
\text { materials and } \\
\text { high frequently } \\
\text { leads to an } \\
\text { increase in } \\
\text { displacement. }\end{array}$ & $\begin{array}{l}\text { Investing more advanced } \\
\text { vehicle with lower fuel } \\
\text { consumption. } \\
\text { Gong Cha could select } \\
\text { more cleaner equipment to } \\
\text { transfer the distribution } \\
\text { equipment. } \\
\text { The IT department could } \\
\text { analyse the delivery route } \\
\text { between the store and } \\
\text { warehouse }\end{array}$ & Long term & \\
\hline
\end{tabular}

Note: Please add these tables in your appendix to show the way you've analysed the interview responses.

\section{Copyrights}

Copyright for this article is retained by the author(s), with first publication rights granted to the journal.

This is an open-access article distributed under the terms and conditions of the Creative Commons Attribution license (http://creativecommons.org/licenses/by/4.0/). 